\title{
MENINGKATKAN HASIL BELAJAR AKUNTANSI DENGAN MENGGUNAKAN STRATEGI PAILKEM MODEL DISKUSI KELOMPOK PADA PESERTA DIDIK KELAS X AKUNTANSI DI SMKN-1 KATINGAN HILIR
}

\author{
Oleh \\ Nopitae Sari* Sonedi** \\ sonedibadli@yahoo.com
}

\begin{abstract}
This study aims to determine the activities of students and know the learning outcomes. The method used by researchers is to use the Classroom Action Research (CAR) design. For data collection techniques used are observations and tests with the research subject is class X Accounting for SMK Negeri 1 Katingan Hilir 2015/2016 Academic Year. The data analysis technique used is qualitative data analysis and quantitative data analysis. The results showed that: (1) learning activities of students of class X Accounting II at SMK Negeri 1 Katingan Hilir using the more active PAILKEM strategy, (2) there was an increase in accounting learning costs for students of class X Accounting II at SMK Negeri 1 Katingan Hilir using the PAILKEM strategy which shows Accounting learning outcomes in the first cycle obtained an average of 76.20 with classical completeness of $65.51 \%$ and in the second cycle the average was 82.41 with classical completeness of $89.65 \%$.
\end{abstract}

(C) Muhammadiyah University of Palangkaraya

Keywords: Accounting Learning Outcomes, PAILKEM Strategy

\begin{abstract}
ABSTRAK
Penelitian ini bertujuan mengetahui akivitas peserta didik dan mengetahui hasil belajar. Metode yang digunakan peneliti adalah menggunakan rancangan Penelitian Tindakan Kelas (PTK). Untuk teknik pengumpulan data yang digunakan adalah observasi dan tes dengan subjek penelitian adalah kelas X Akuntansi SMK Negeri 1 Katingan Hilir Tahun Pelajaran 2015/2016. Teknik analisis data yang digunakan adalah analisis data kualitatif dan analisis data kuantitatif. Hasil penelitian menunjukkan bahwa: (1) aktivitas belajar peserta didik kelas X Akuntansi II SMK Negeri 1 Katingan Hilir dengan menggunakan strategi PAILKEM lebih aktif, (2) ada peningkatan hail belajar Akuntansi peserta didik kelas X Akuntansi II SMK Negeri 1 Katingan Hilir menggunakan strategi PAILKEM yang menunjukkan hasil belajar Akuntansi pada siklus I diperoleh rata-rata 76,20 dengan ketuntasan klasikal 65,51\% dan pada siklus II rata-rata 82,41 dengan ketuntasan klasikal 89,65\%.
\end{abstract}

(C) Universitas Muhammadiyah Palangkaraya

Kata Kunci: Hasil Belajar Akuntansi, Strategi PAILKEM. 


\section{PENDAHULUAN}

Pendidikan dilakukan manusia dalam melakukan aktivitas kehidupan sehari-hari baik secara formal, non formal maupun informal. Pendidikan tersebut dilakukan manusia dalam rangka memperbaiki dan meningkatkan taraf hidupnya, melalui proses pendidikan diharapkan manusia menjadi cerdas atau memiliki kemampuan, yang biasa dikenal dengan Skill dalam menjalani kehidupan.Dengan adanya kemampuan tersebut memampukan manusia untuk bergaul dalam masyarakat, mampu menolong sesama manusia, berkarya, bertahan hidup serta mampu mengaktualisasi diri dalam masyarakatnya.

Pendidikan yang terbaik tersebut merupakan pendidikan yang unggul dan bermutu, dengan bermutunya pendidikan tersebut maka para pelaku pendidikan tersebut mampu memberikan yang terbaik bagi pelanggan yang tidak lain adalah sesama manusia yang merupakan pengguna jasa pendidikan. Untuk mendapatkan pendidikan bermutu tidaklah semudah membalikkan telapak tangan ada proses dan langkah-langkah yang harus dilaksanakan sehingga pelaksanaan pendidikan tersebut berhasil dan memiliki mutu yang baik. Keberhasilan dalam proses kegiatan belajar mengajar sangat tergantung pada kemampuan pengajar dalam menentukan tujuan belajar peserta didik.

Belajar merupakan kegiatan paling pokok dalam proses belajar mengajar manusia. Terutama dalam pencapaian suatu lembaga pendidikan atau sekolah. Hal ini menunjukkan bahwa berhasil tidaknya suatu pencapaian tujuan pendidikan tergantung kepada bagaimana proses belajar mengajar yang dialami oleh individu.

Menurut Nasution (dalam Hamzah B. Uno dan Nurdin Mohamad, 2014:141), belajar adalah aktivitas yang menghasilkan perubahan pada diri individu yang belajar, baik aktual maupun potensial. Perubahan itu pada dasarnya berupa di dapatkannya kemungkinan baru, yang berlaku dalam waktu yang relatif lama. Belajar adalah suatu proses sebagai hasil dari terbentuknya respons utama,dengan syarat bahwa perubahan atau munculnya tingkah baru itu di sebabkan oleh adanya kematangan atau oleh adanya perubahan sementara karena suatu hal.

Sedangkan menurut pandangan Gagne (dalam Dimyati dan Mudjiono, 2006:10), belajar merupakan kegiatan yang kompleks. Hasil belajar berupa kapabilitas. Setelah belajar orang memiliki keterampilan, pengetahuan, sikap, dan nilai. Timbulnya kompetensi tersebut adalah dari stimulasi yang berasal dari lingkungan, dan proses kognitif yang dilakukan oleh pembelajar. Dengan demikian, belajar adalah seperangkat proses kognitif yang mengubah sifat stimulasi lingkungan, melewati pengolahan informasi, menjadi kapabilitas baru.

Adapun Menurut Witherington (dalam Nana Syaodih Sukmadinata, 2011:155), berpendapat bahwa belajar adalah "suatu perubahan di dalam kepribadian yang menyatakan diri 
sebagai suatu pola baru dari reaksi berupa kecakapan, sikap, kebiasaan, kepribadian atau suatu pengertian".

Berdasarkan pendapat di atas dapat disimpulkan bahwa belajar ialah suatu proses usaha yang dilakukan seseorang untuk memperoleh suatu perubahan tingkah laku yang baru secara keseluruhan, sebagai hasil pengalamannya sendiri dalam interaksi dalam lingkungannya.

Nana Syaodih Sukmadinata, (2011:102) Hasil belajar atau achievement merupakan realisasi atau pemekaran dari kecakapan-kecakapan potensial atau kapasitas yang dimiliki seseorang. Penguasaan hasil belajar oleh seseorang dapat dilihat dari perilakunya, baik perilaku dalam bentuk penguasaan pengetahuan,keterampilan berpikir maupun keterampilan motorik.Hampir sebagian terbesar dari kegiatan atau perilaku yang diperlihatkan seseorang merupakan hasil belajar. Di sekolah hasil belajar ini dapat dilihat dari penguasaan peserta didik akan mata pelajaran yang ditempuhnya.

Hasil belajar adalah perubahan tingkah laku yang mencakup bidang kognitif, afektif, dan psikomotor yang dimiliki peserta didik setelah menerima pengalaman belajarnya. Hasil belajar dalam penelitian ini adalah hasil belajar akuntansi.

Menurut Suharsimi, (2008:33) hasil belajar akuntansi merupakan: tingkat penguasaan kompetensi peserta didik baik dari segi kognitif, afektif maupun psikomotorik dalam mata pelajaran akuntansi yang ditunjukkan dengan nilai tes atau angka nilai yang diberikan oleh guru.
Menurut Samryn,(2012 :17) Hasil belajar akuntansi juga dapat diartikan sebagai suatu hasil yang telah dicapai oleh peserta didik dalam mempelajari mata pelajaran akuntansi yang diperoleh dari hasil tes yang dinyatakan dalam bentuk skor atau angka.

Menurut J. R. David (dalam Wina Sanjaya, 2006:126) Strategi pembelajaran adalah perancanaan yang berisi tentang rangkaian kegiatan yang didesain untuk mencapai tujuan pendidikan tertentu. Jadi dapat disimpulkan bahwa strategi pembelajaran merupakan strategi yang perlu diperhatikan dan dicermati dalam menunjang proses pembelajaran.

Menurut Kemp (dalam Hamzah B. Uno dan Nurdin Mohamad, 2014:3) menjelaskan bahwa strategi pembelajaran PAILKEM adalah suatu kegiatan pembelajaran yang harus dikerjakan guru dan peserta didik agar tujuan pembelajaran dapat dicapai secara efektif dan efisien.

Strategi pembelajaran merupakan cara yang akan dipilih dan digunakan oleh seorang pengajar untuk menyampaikan materi pembelajaran, sehingga akan memudahkan peserta didik mencapai tujuan yang dikuasai diakhir kegiatan belajar. Strategi pembelajaran merupakan cara yang berbeda untuk mencapai hasil pembelajaran yang berbeda dibawah kondisi yang berbeda. Variable strategi pembelajaran diklasifikasikan menjadi yaitu Strategi Pengorganisasian, Strategi penyampaian, dan Strategi pengelolaan.

Menurut Hamzah B. Uno dan Nurdin Mohamad (2014:10) Mengungkapkan bahwa PAILKEM 
merupakan sinonim dari Pembelajaran Aktif Inovatif Lingkungan Kreatif Efektif dan Menarik, yang merupakan salah satu strategi yang dapat diterapkan dalam kegiatan pembelajaran. Strategi PAILKEM senantiasa memposisikan guru sebagai orang yang menciptakan suasana belajar yang kondusif atausebagai fasilitator dalam

belajar, sementara peserta didik sebagai peserta belajar yang harus aktif, inovatif, lingkungan dimanfaatkan sebagai sumber belajar, kreatif, efektif, dan menarik. Dimaksudkan dengan strategi karena bidang garapannya tertuju pada bagaimana cara, (1) pengorganisasian materi pembelajaran, (2) Menyampaikan atau menggunakan metode pembelajaran, (3) Mengelola pembelajaran sebagaimana yang dikehendaki oleh ilmuwan pembelajaran selama ini.

PAILKEM merupakan sinonim dari Pembelajaran Aktif, Inovatif, Lingkungan, Kreatif, Efektif, dan Menarik. PAILKEM bukanlah tujuan dari kegiatan pembelajaran, tetapi merupakan salah satu strategi yang digunakan untuk mengoptimalkan proses pembelajaran. Dalam proses pembelajaran PAILKEM terjadi dialog interaktif antara siswa dengan siswa, siswa dengan guru atau siswa dengan sumber belajar lainnya.

Berdasarkan pendapat para ahli di atas, maka peneliti menyimpulkan PAILKEM merupakan pembelajaran yang memungkinkan peserta didik melakukan kegiatan yang beragam untuk mengembangkan keterampilan, sikap dan pemahaman. Guru menggunakan berbagai sumber belajar dan alat bantu termasuk pemanfaatan lingkungan sebagai sumber belajar agar pembelajaran lebih menarik, menyenangkan dan efektif.

\section{METODE PENELITIAN}

Penelitian ini adalah Penelitian Tindakan Kelas (PTK) adalah penelitian yang dilakukan oleh guru di kelas atau sekolah tempat ia mengajar dengan penekanan pada penyempurnaan atau peningkatan proses dan praktis pembelajaran. Dalam proses penelitian ini tujuan peneliti adalah untuk mengetahui mengaktifkan aktivitas dan meningkatkan hasil belajar peserta didik.

PTK dilaksanakan dengan strategi siklus yang berangkat dari identifikasi masalah yang dihadapi oleh guru, penyusunan rencana tindakan, pelaksanaan tindakan, observasi tindakan, dan refleksi. Setiap siklus terdiri dari empat tahap, yakni perencanaan tindakan, pelaksanan tindakan, observasi dan interprestasi, dan analisis dan refleksi.

\section{HASIL PEMBAHASAN}

Berdasarkan hasil penelitian deskripsi data yang disajikan terdiri dari tiga jenis yaitu, data pra tindakan, data siklus I, dan data siklus II. Data pra tindakan adalah data hasil tes awal sebelum diterapkan tindakan kelas pada proses kegiatan pembelajaran yang dilakukan oleh peneliti. Data siklus I adalah hasil data yang diperoleh dari kegiatan tindakan kelas yang dilakukan pada proses kegiatan pembelajaran siklus I, dan data siklus II adalah hasil 
proses kegiatan pembelajaran tindakan kelas yang dilakukan pada siklus II.

Pada tahap awal di saat observasi sebelum menerapkan siklus I dan siklus II dengan menggunakan strategi PAILKEM aktivitas belajar peserta didik masih rendah. Namun ketika diterapkan pada siklus I aktivitas belajar peserta didik dari 29 peserta didik ratarata hasil pengamatan aktivitas yaitu 3,0 dengan kriteria baik dan pada siklus II dari 29 peserta didik rata-rata pengamatan hasil aktivitas meningkat menjadi 3,3 dengan kriteria baik. Hasil belajar peserta didik bahwa pada hasil tes pra tindakan peserta didik memperoleh rata-rata 60,68 dengan ketuntasan klasikal 34,48\%, sedangkan pada siklus I peserta didik memperoleh rata-rata 76,20 dengan ketuntasan klasikal 65,51 akan tetapi belum memenuhi ketercapaian ketuntasan hasil belajar peserta didik secara klasikal, dan pada siklus II menunjukkan adanya peningkatan yaitu,memperoleh rata-rats 82,41 dengan ketuntasan klasikal $89,65 \%$ telah memenuhi ketercapaian ketuntasan hasil belajar peserta didik secara klasikal sehingga peneliti menggangap pada siklus II ini berhasil. Namun pada hasil tes belajar peserta didik pada pra tindakan sampai post test terdapat tiga orang peserta didik yang tidak tuntas maka ini menjadi hasil kekurangan dalam pelaksanaan penelitian ini.

Berdasarkan hasil pembelajaran diatas dengan menggunakan strategi PAILKEM dapat meningkatkan hasil belajar peserta didik. Jenis penelitian yang dilakukan adalah penelitian kualitatif yang bersifat deskriptif.
Pengumpulan data yang digunakan adalah observasi, wawancara dan dokumentasi. Hasil penelitian yang didapat menjelaskan selama melakukan penelitian selama 4xpertemuan dengan menggunakan media audio visual telah terjadi peningkatan hasil belajar peserta didik. Hasil penelitiannya menunjukkan perolehan nilai pada siklus I sudah masuk kategori baik dengan nilai ratarata 7,73, pada siklus II meningkat nilai rataratanya menjadi 7,93 dan pada siklus III meningkat lagi menjadi 8,2.

Ike Verawati Fadilah (2014) penelitiannya berjudul "Penerapan Strategi PAILKEM (Pembelajaran Aktif Inovatif Lingkungan Kreatif Efektif Menarik) Untuk Meningkatkan Kemampuan Komunikasi Matematika Materi Dimensi Tiga Siswa Kelas X di MA At Thohiriyah Tahun Pelajaran 2013/2014". Dalam penelitian ini digunakan metode tes, wawancara, observasi. Tes digunakan untuk mengetahui tingkat pemahaman konsep siswa tentang materi. Tes ini berupa tes tulisan dan tes lisan. Tes tulis berguna untuk mengetahui tingkat kemampuan siswa pada materi. Sedangkan untuk tes lisan berguna untuk mengetahui kemampuan berkomunikasi siswa pada mata pelajaran matematika. Observasi untuk melihat aktivitas siswa dalam pembelajaran matematika. Disini yang diamati adalah aktifitas siswa dan kegiatan guru. Wawancara dilakukan kepada siswa dan kepada guru bidang studi matematika untuk mencari tahu informasi - informasi yang mendukung pengumpulan data. Jenis penelitian ini adalah Penelitian Tindakan Kelas (PTK). PTK ini dilaksanakan dalam 
satu tindakan yang terdiri dari dua siklus. Pada setiap siklus terdiri dari perancanaan tindakan, pelaksanaan tindakan, observasi, dan refleksi. Dari hasil penelitian menunjukkan bahwa penggunaan strategi pembelajaran Pailkem untuk komunikasi matematika siswa telah mengalami peningkatan dari siklus 1 ke siklus II dengan kriteria nilai baik. Dari hasil keaktifan siswa mengalami peningkatan dari $73.33 \%$ meningkat menjadi $84.82 \%$ dari hasil ketuntasan belajar seluruh siswa yang mulanya nilai presentase $62.50 \%$ meningkat menjadi $81.25 \%$ dan untuk hasil kemampuan komunikasi siswa yang awalnya hanya $81.78 \%$ telah meningkat menjadi $88.30 \%$ berdasarkan hasil penelitian maka dapat dikatakan bahwa penerapan strategi PAILKEM dapat meningkatkan kemampuan komunikasi matematika pada materi dimensi tiga siswa kelas $\mathrm{X}$ di MA At Thohiriyah.

\section{KESIMPULAN}

Aktivitas belajar peserta didik dengan menggunakan strategi PAILKEM peserta didik menjadi aktif dan mengalami peningkatan disetiap siklus. Siklus I jumlah skor yang diperoleh 18 dengan persentase $75 \%$ kriteria baik dan pada siklus II jumlah skor yang diperoleh peserta didik 20 dengan persentase $83 \%$ kriteria baik.

Adanya peningkatan hasil belajar peserta didik pada mata pelajaran Akuntansi materi mutasi dana kas kecil, di kelas X Akuntansi SMK Negeri 1 Katingan Hilir. Hal ini terlihat dari data hasil belajar peserta didik pada proses pra tindakan memperoleh rata-rata 60,68 dengan ketuntasan klasikal $34,48 \%$, sedangkan pada siklus I memperoleh rata- rata 76,20 dengan ketuntasan klasikal $65,51 \%$, dan pada siklus II mengalami adanya peningkatan yaitu, memperoleh rata-rata 82,41 dengan ketuntasan klasikal 89,65\%.

\section{DAFTAR PUSTAKA}

Dimyati dan Mudjiono. 2006. Belajar dan Pembelajaran. Jakarta:PT Rineka Cipta.

Hamzah B. Uno dan Nurdin Mohamad. 2014. Belajar dengan Pendekatan PAILKEM: Pembelajaran Aktif, Kreatif, Inofatif, Lingkungan, Kreaktif, Menarik. Jakarta:Bumi Aksara.

Nana Syaodih Sukmadinata. 2011. Landasan Psikologi Proses Pendidikan. Bandung:PT Remaja Rosdakarya.

Samryn. 2012. Pengantar Akuntansi Mudah Membuat Jurnal Dengan Pendekatan Siklus Transaksi. Jakarta: PT Rajagrafindo Persada.

Suharsimi, Arikunto. 2008. FaktorFaktor yang Mempengaruhi Hasil Belajar. Jakarta: Rineka Cipta.

Verawati, Fadilah Ike. 2014. Penerapan Strategi PAILKEM materi dimensi Tiga untuk Meningkatkan Kemampuan Komunikasi Matematika Siswa kelas X di MA At-Thohiriyah Ngantru. http://repo.iaintulungagung.ac.id/364.(25/12/201 5).

Sanjaya, Wina. 2006. Strategi Pembelajaran Berorientasi Standar Proses Pendidikan. Jakarta:Kencana Prenada Media Group. 